Elizabeth M. Renehan MSc MD, *

Rebecca A. Peterson MD FRCPC, $\dagger$

John P. Penning MD FRCPC, *

Ola P. Rosaeg MB FRCPC, *

Donald Chow MD FRCSC DIP SP MED

\section{Visualization of a} looped and knotted epidural catheter with a guidewire

Purpose: To describe the management of a looped and knotted epidural catheter after analgesia for labour and delivery.

Clinical Features: Obstetrical epidural pain relief was provided for a 37-yr old woman in early labour. A 20gauge Portex ${ }^{\circledR}$ catheter was inserted at the L2 - L3 interspace. Six centimetres of catheter was left in the epidural space. After vaginal delivery the catheter could not be removed. The catheter was left in situ for $24 \mathrm{hr}$. Repeated attempts at removal were again unsuccessful. The epidural catheter was not visible with fluoroscopy and it was impossible to inject radiopaque dye into the catheter. However, we successfully advanced a 0.016 inch guidewire through the epidural catheter and radiologically demonstrated a knot and part of a loop. The catheter was removed by an orthopedic surgeon using blunt dissection under local anesthetic from the soft tissue just lateral to the interspinous ligament.

Conclusions: A knot can be a rare cause of a trapped epidural catheter. A suggested approach to the trapped lumbar epidural catheter: 1) Gentle traction on the catheter with the patient in various positions and in various degrees of lumbar flexion. 2) Test for catheter patency by injecting sterile, preservative-free, normal saline through the catheter. 3) Radiological imaging to determine if a knot is present and to determine its location, using radiopaque contrast for patent catheters or a guidewire for occluded catheters. 4) The approach to definitive management is based on the position of the knot. This can range from excision under local anesthetic to consultation with a surgical specialty for more invasive retrieval.

Objectif : Présenter la démarche visant à retirer un cathéter péridural retrouvé enroulé et noué après une analgésie pour le travail obstétrical et l'accouchement.

Éléments cliniques : Au début du travail, l'analgésie a été administrée par voie péridurale à une femme de 37 ans. On a inséré un cathéter Portex ${ }^{\circledR}$ de calibre 20 dans l'espace entre L2 et L3. Six centimètres de cathéter ont été laissés dans l'espace péridural. Après l'accouchement vaginal, on ne pouvait plus retirer le cathéter. II a donc été laissé in situ pendant $24 \mathrm{~h}$. Les essais subséquents pour le retirer ont aussi échoué. Le cathéter n'était pas visible à la fluoroscopie et l'injection de colorant radio-opaque à l'intérieur était impossible. Toutefois, nous avons réussi à y insérer un guide souple de 0,016 pouce et nous avons pu, par radiographie, démontrer un noeud et un début d'enroulement. Le cathéter a été retiré par un chirurgien orthopédiste en utilisant la dissection par clivage, sous anesthésie locale, à partir des tissus mous juste à côté du ligament interépineux.

Conclusion : Un noeud peut empêcher, dans de rares cas, le retrait d'un cathéter péridural. Une démarche possible, dans le cas d'un cathéter péridural lombaire bloqué, consiste à : I) Appliquer une faible traction sur le cathéter, le patient adoptant diverses positions selon différents degrés de flexion lombaire. 2) Tester la perméabilité du cathéter en y injectant un soluté physiologique, stérile et sans agent conservateur. 3) Vérifier, par imagerie radiologique, la présence d'un noeud et en déterminer la localisation en utilisant des produits de contraste radioopaques, si le cathéter est perméable, ou un guide souple si le cathéter est obstrué. 4) Procéder finalement en se basant sur la position du noeud. Ce qui peut aller de l'excision sous anesthésie locale à la consultation d'un chirurgien spécialisé qui utilisera une technique plus effractive pour retirer le cathéter.

From the Departments of Anesthesiology* and Radiology, $\nmid$ and the Division of Orthopaedic Surgery, $\ddagger$ University of Ottawa, Ottawa Hospital-Civic Campus, Ottawa, Ontario, Canada.

Address correspondence to: Dr. E.M. Renehan, Department of Anesthesiology, Ottawa Hospital, Civic Campus, 1053 Carling Avenue,

Ottawa, Ontario, KIY 4E9 Canada. Phone: 613-761-4169; Fax: 613-761-5209; E-mail: Renehane@yahoo.com Accepted for publication December 12, 1999. 


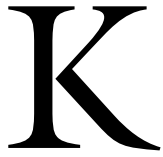

NOTTING of an epidural catheter is a very rare complication of lumbar epidural analgesia. We report the use of an angiography wire to visualize a loop and knot in an occluded epidural catheter after uneventful infusion of a local anesthetic/opioid mixture for pain relief during labour and delivery.

\section{Case Report}

A healthy, 37-yr-old multigravida (G4P2Al, height 152 $\mathrm{cm}$, weight $58 \mathrm{~kg}$ ) presented in early labour at $38 \mathrm{wk}$ gestation. Ninety minutes after admission to the labour and delivery unit, she requested epidural analgesia. The epidural space was identified in the $\mathrm{L}_{2-3}$ interspace at a depth of $5 \mathrm{~cm}$ using the loss of resistance to air technique with a 16-gauge Tuohy needle A 20-gauge, Portex ${ }^{\circledR}$, polyurethane, closed end, epidural catheter with three ports was easily inserted with the patient in sitting position. The catheter was threaded to the $16 \mathrm{~cm}$ mark, the needle was removed, and the catheter was left with the $11 \mathrm{~cm}$ mark at the skin. This left $6 \mathrm{~cm}$ of catheter in the epidural space. Following a test dose of $3 \mathrm{ml}$ lidocaine $1.5 \%$ with 1:200,000 epinephrine, the catheter was taped in place. Eight $\mathrm{ml}$ bupivacaine $0.1 \%$ and fentanyl $3 \mu \mathrm{g} \cdot \mathrm{ml}^{-1}$ was administered after no signs of intravascular or subarachnoid cannulation followed the lidocaine test dose. A sensory level of $\mathrm{T}_{10}$ was achieved bilaterally after five minutes and the patient was comfortable.

Labour was complicated by a prolonged active phase and multiple variable fetal heart rate decelerations. Pain relief was maintained with an infusion of bupivacaine $0.1 \%$ and fentanyl $2 \mu \mathrm{g} \cdot \mathrm{ml}^{-1}$. The infusion was initiated at $12 \mathrm{ml} \cdot \mathrm{hr}^{-1}$. During the course of labour, three boluses of $5 \mathrm{ml}$ each of the infusion solution were given. With each bolus the infusion rate was increased by $2 \mathrm{ml} \cdot \mathrm{hr}^{-1}$ to a final rate of $18 \mathrm{ml} \cdot \mathrm{hr}^{-1}$. The patient remained comfortable and experienced minimal motor blockade.

Vaginal delivery of a healthy infant occurred approximately six hours after admission. The epidural catheter remained in situ until approximately two hours after delivery when the sensory and motor blocks had regressed. At this time the attending nurse attempted to remove the catheter but was unsuccessful. Before any further attempts, the patient ambulated to the washroom and back to the bed. The catheter was still $11 \mathrm{~cm}$ at the skin. During subsequent attempts at withdrawal, gentle traction was placed on the catheter with the patient in varying degrees of lumbar flexion and extension while sitting, lying in lateral decubitus position, and standing. Firm resistance to traction was felt. The catheter stretched somewhat with traction but did not move.We were unable to inject sterile saline through the catheter at this time.

After discussion with the patient and her husband, the catheter was retaped and left in situ for $24 \mathrm{hr}$. When reassessed the next day, the catheter remained at $11 \mathrm{~cm}$ at the skin. Repeated attempts at removal, similar to those described above, continued to be unsuccessful. We then proceeded with radiographic imaging to outline the position and orientation of the catheter. Although the epidural catheter was reported to be radiopaque on the packaging material, it could not be identified with fluoroscopy. We were unable to inject radiopaque dye through the catheter. A 0.016 inch guidewire (Radiofocus ${ }^{\mathrm{TM}}$ Guide Wire M, Terumo Corporation, Tokyo, Japan) was introduced. It readily advanced inside the catheter with minimal resistance and a knot in the catheter was demonstrated. At this point increased resistance was felt and further advancement of the wire was not attempted.

Lateral (Figure 1) and oblique (Figure 2) X-ray views with the wire in place showed a knot external to the epidural space at the level of the interspinous ligament. From these views, it was not possible to determine whether the knot was within or lateral to the interspinous ligament. An orthopedic surgeon using blunt dissection identified the knot and a loop in the catheter within the paraspinous soft tissues just lateral to the interspinous ligament. The catheter was removed intact with no complications and the patient was discharged home the next day with no residual effects.

On examination of the catheter, there was a knot $3.7 \mathrm{~cm}$ from the tip of the catheter forming the base of a $1 \mathrm{~cm}$ high loop (Figure 3 ). The tip of the angiography wire was visible at the apex of the loop. The 5 $\mathrm{cm}$ mark on the catheter was also visible near the apex of the loop (Figure 4).

\section{Discussion}

We have described the management of a very unusual complication of epidural catheterization. There have been eleven cases of knotted epidural catheters reported in the literature. ${ }^{1-10}$ Eight of these involved tight knots near the distal tip of the catheter. ${ }^{2-7}$ One case reported knotting of the catheter around strands of ligamentum flavum. ${ }^{8}$ Before the current report, there were two cases reported in the German literature of epidural catheters that were looped and knotted in the epidural space..$^{9,10}$

In eight of the eleven reports, the catheter was removed intact with firm traction. ${ }^{1-5,10}$ One of these patients was under general anesthesia with muscle paralysis. ${ }^{7}$ In three of the eleven cases, attempts at removing the catheters with traction caused catheter 


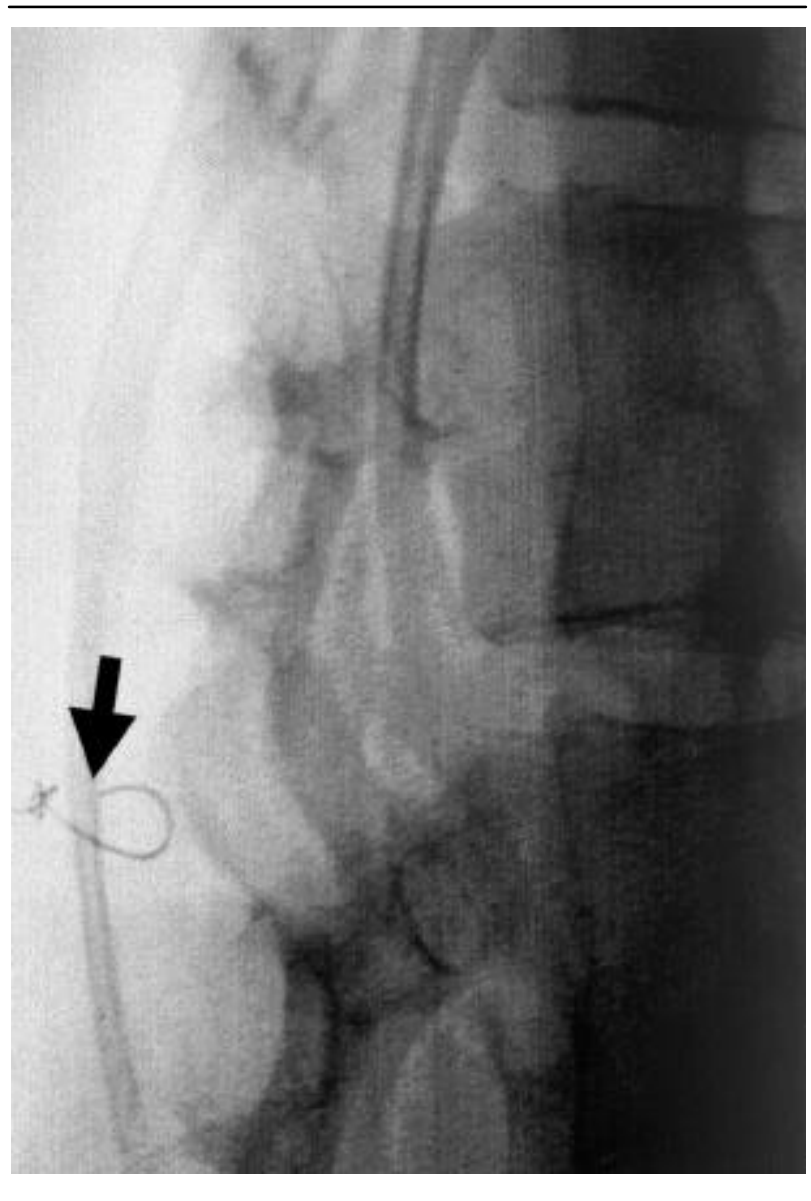

FIGURE 1 Lateral lumbar spine $x$-ray showing the guidewire within the epidural catheter. The arrow shows the tip of the guidewire at the apex of the loop. Corresponding position in the excised catheter in Figure 3. Vertical structure behind the catheter is a rib.

breakage and necessitated surgical excision of the retained piece of catheter. ${ }^{6,8,9}$

Radiological visualization of the catheter was attempted in five cases. Plain X-rays and ultrasound provided information on the level at which the catheter was trapped but no accurate determination of the outline of the catheter was obtained. ${ }^{2,7,9}$ The successful use of radiopaque dye and computed tomographic scanning have been described. ${ }^{3,11-13}$ There is also a report of a radiopaque wire enhancing the imaging of an occluded epidural catheter. ${ }^{10}$

In our case, we believe that the loop and knot formed from two loops that developed in the catheter. By carefully taking the knot apart, we found that the two loops had intertwined with one loop tightened on the base of the other to form the knot and loop that

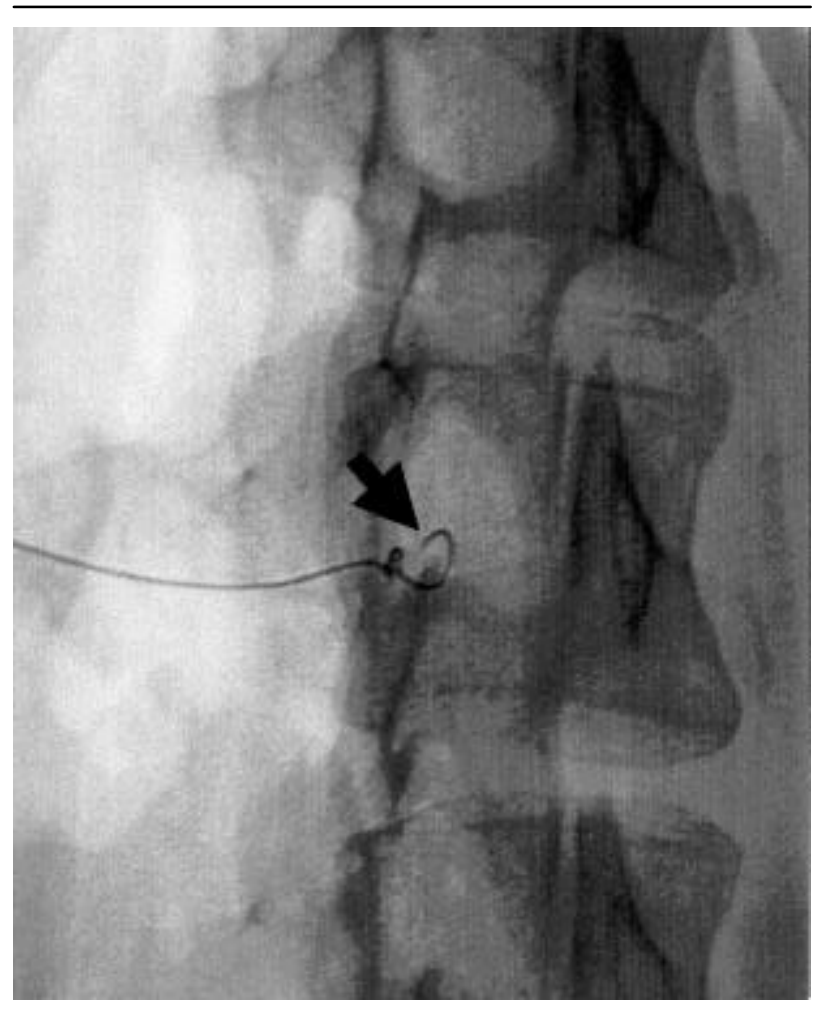

FIGURE 2 Oblique lumbar spine $\mathrm{x}$-ray showing the guidewire in the epidural catheter. Arrow corresponds to the guidewire position shown in Figure 3.

was excised from the paraspinous soft tissue just lateral to the interspinous ligament.

The conclusion of many of the reports of knotted epidural catheters is that insertion of excessive amounts of catheter into the epidural space is a causative factor in knot formation. ${ }^{5-8,10}$ However, the optimal amount of catheter to insert into the epidural space to minimize complications in still a matter of debate. Some authors have recommended the insertion of no more than $3-4 \mathrm{~cm}$ of catheter into the epidural space ${ }^{7,14}$ or no more than $5 \mathrm{~cm}^{2,6}$ While others routinely insert $5-6 \mathrm{~cm}$ of catheter into the epidural space. ${ }^{15} \mathrm{~A}$ prospective, randomized trial of 800 women in active labour concluded that the optimal depth of insertion of single orifice catheters into the epidural space to avoid complications and provide adequate pain relief was $2 \mathrm{~cm}$ if rapid labour is anticipated and $6 \mathrm{~cm}$ if prolonged labour or cesarean section are expected. ${ }^{14} \mathrm{~A}$ similar trial using multi-orifice catheters in 100 women in active labour concluded that the optimal depth of insertion was $5 \mathrm{~cm}$. In Beilin's study, insertion of $7 \mathrm{~cm}$ of catheter into the 


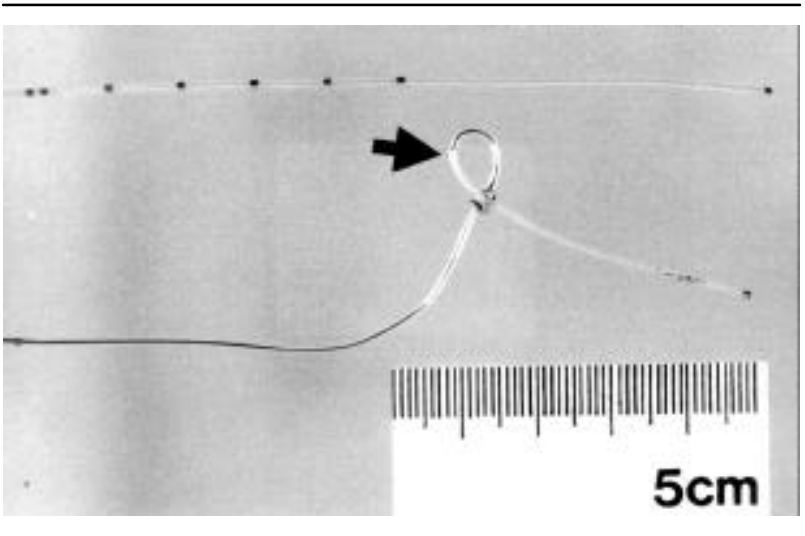

FIGURE 3 Excised epidural catheter (below) shown with an unused catheter for comparison. Many of the length markings visible on the top catheter had been rubbed off the knotted catheter while it was in situ.

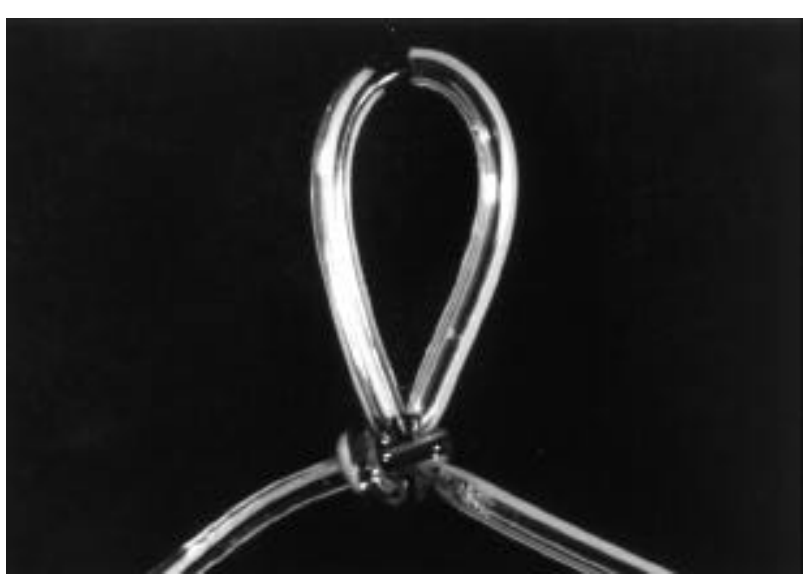

FIGURE 4 Enlargement of the knot and loop showing the $5 \mathrm{~cm}$ marking near the apex of the loop.

epidural space was associated with increased vascular cannulation and inadequate analgesia. ${ }^{17}$ The $6 \mathrm{~cm}$ of catheter inserted into the epidural space in the current case was not excessive when compared with published guidelines. Therefore, a knot may form in an epidural catheter without insertion of an excessive amount of catheter into the epidural space.

Knotted epidural catheters are a very rare but reported complication of epidural anesthesia. Multiple reports show that they can often be removed intact with traction. However, catheter breakage is a reported risk potentially entailing extensive surgical explo- ration. Even if surgical removal of a retained catheter fragment is not attempted, complications may still arise. ${ }^{18} \mathrm{We}$ suggest the following approach to the management of a trapped lumbar epidural catheter:

1. Gentle traction on the catheter with the patient in various positions and in various degrees of lumbar flexion and extension. There is some evidence that the force required for catheter removal is reduced when the patient is in the lateral decubitus position. ${ }^{19}$

2. Determination of the patency of the catheter by attempting to inject sterile, preservative-free normal saline through the catheter.

3. Radiological imaging with radiopaque dye if the catheter is patent or with a guidewire if the catheter is occluded.

4. Radiological information on the position relative to the epidural space and orientation of a knot to guide the decision on whether consultation with a surgical specialty is required.

\section{References}

1 Bromage PR. Epidural Analgesia. Philadelphia: WB Saunders, 1978: 230-1.

2 Browne RA, Politi VL. Knotting of an epidural catheter: a case report. Can Anesth Soc J 1979; 26: $142-4$.

3 Nicholson MJ, Hehre FW, Muechler HC. Complication associated with use of extradural catheter in obstetric anesthesia. Anesth Analg 1965; 44: 245-7.

4 Saberski LR, Schwartz JI, Greenhouse BB, Kennedy TM, Ullman DA. A unique complication of a lumbar epidural catheter. Anesthesiology 1988; 69: 634-5.

5 Fibuch EE, McNitt JD, Cussen T. Knotting of the Theracath $^{\mathrm{TM}}$ after an uneventful epidural insertion for Cesarean delivery (Letter). Anesthesiology 1990; 73: 1293.

6 Chun L, Karp M. Unusual complications from placement of catheters in caudal canal in obstetrical anesthesia. Anesthesiology 1964; 27: 96-7.

7 Gozal D, Gozal Y, Beilin B. Removal of knotted epidural catheters. Reg Anesth 1996; 21: 71-3.

8 Blass NH, Roberts RB, Wiley JK. The case of the errant epidural catheter. Anesthesiology 1981; 54: 419-21.

9 Riegler R, Pernetzky A Unmovable epidural catheter due to a sling and a knot: a rare complication of epidural anesthesia in obstetrics. (German) Reg Anesth 1983; 6: 19-21.

10 Striebel HW, Dopjans D. Knotting of an peridural catheter. (German) Reg Anesth 1991; 14: 104-5.

11 Muneyuki M, Shirai K, Inamoto A. Roentgenographic analysis of the positions of catheters in the epidural space. Anesthesiology 1970; 33: 19-24. 
12 Sidhu MS, Asrani RV, Bassell GM. An unusual complication of extradural catheterization in obstetric anaesthesia. Br J Anaesth 1983; 55: 473-5.

13 Jongleux EF, Miller R, Freeman A. An entrapped epidural catheter in a postpartum patient. Reg Anesth Pain Med 1998; 23: 615-7.

14 Brown DL. Spinal, epidural and caudal anesthesia. In: Miller RD (Ed.). Anesthesia 4th ed. New York: Churchill Livingstone Inc., 1994: 1522-5.

15 Stuart AL, McDavid AJ. Knotted epidural catheters (Letter). Reg Anesth 1996; 21: 606.

16 D'Angelo R, Berkebile BL, Gerancher JC. Prospective examination of epidural catheter insertion. Anesthesiology 1996; 84: 88-93.

17 Beilin $\Upsilon$, Bernstein HH, Zucker-Pinchoff B. The optimal distance that a multiorifice epidural catheter should be threaded into the epidural space. Anesth Analg 1995; 81: 301-4.

18 Staats PS, Stinson MS, Lee RR. Lumbar stenosis complicating retained epidural catheter tip. Anesthesiology 1995; 83: 1115-8.

19 Boey SK, Carrie LES. Withdrawal forces during removal of lumbar extradural catheters. Br J Anaesth 1994; 73: 833-5. 